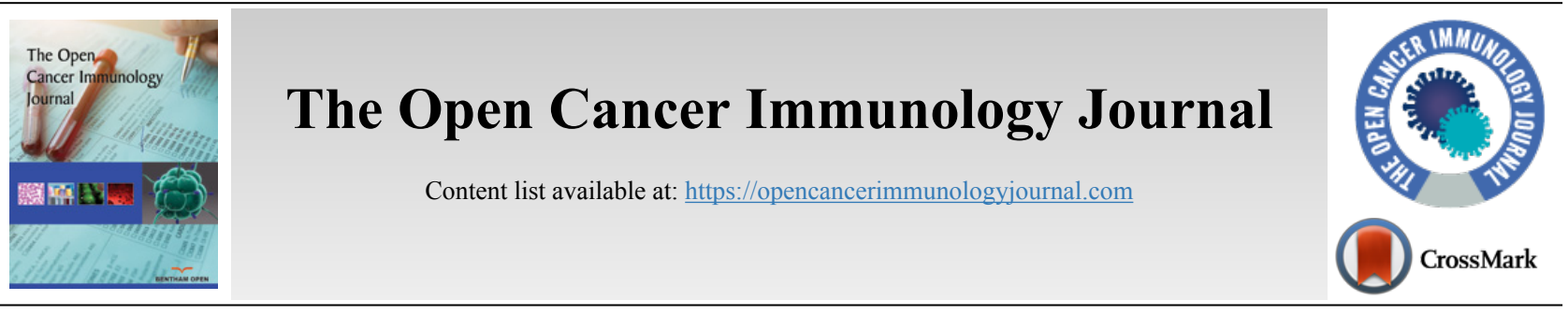

RESEARCH ARTICLE

\title{
Peripheral Blood Oxygen Saturation: A Non-invasive Prognostic Marker in Cancer Patients Treated with Radiation Therapy- A Pilot Study
}

\author{
Savitha David $^{1, *}$ and V Lokesh ${ }^{1}$ \\ ${ }^{1}$ Department of Radiation Oncology, KIDWAI memorial institute of Oncology, Bengaluru, India
}

\begin{abstract}
:
Aims:

1. To evaluate the prognostic value of $\mathrm{SpO} 2$ in cancer patients 2 . To correlate between daily $\mathrm{SpO} 2$ values and tumor response to radiation.

Background:

Tumor hypoxia is an important prognostic factor in Oncology. It plays an important role in tumorogenesis, radiation resistance and tumor progression. Many invasive and in-vitro methods are available to assess the hypo-oxygenated status of tumors.

Objective:

We evaluated if SpO2 values measured from pulse oximetry could be used as an adjunct prognostic and predictive factor in oncology patients.

Methods:

Ten consecutive patients with locally advanced, non-metastatic disease were evaluated. Daily SpO2 measurements throughout the treatment and weekly haemoglobin values were noted. All patients received radical intent radiation therapy. Patients were categorised into two groups: poor $\mathrm{SpO} 2(<97 \mathrm{mmHg})$ and better $\mathrm{SpO} 2(\geq 98 \mathrm{mmHg})$.

Results:

Tumour response was higher in patients with better SpO2 $(\geq 98 \mathrm{mmHg})$. Patients with poor $\mathrm{SpO} 2(<97 \mathrm{mmHg})$ presented with bulkier disease at diagnosis.

Conclusion:

Role of $\mathrm{SpO} 2$ as a prognostic and predictive factor should be explored further with in vitro and $\mathrm{pH}$ studies.
\end{abstract}

Keywords: Pulse oximetry, Prognostic, Cancer, SpO2 Value, Tumorogenesis, Oncology.

\begin{tabular}{|l|l|l|l}
\hline Article History & Received: March 26, 2020 & Revised: June 8, 2020 & Accepted: June 9, 2020
\end{tabular}

\section{INTRODUCTION}

Prognostic and predictive factors have been the Holy Grail of Oncology. To find ideal prognostic factors, which can choose patients for a particular treatment, tailor the intervention, reduce toxicities and improve survival, has been science's pursuit. Currently, many modalities are available for diagnosis and prognostication, such as imaging, scopies, tumour markers and the gold standard histopathological analy-

* Address correspondence to this author at Department of Radiation Oncology, KIDWAI memorial institute of oncology, Bengaluru, India; Tel: 9980836554; E-mail: dr.sav.david@gmail.com sis [1].Nevertheless, they have their own set of disadvantages, such as they are invasive, expensive and require expertise. Research has been ongoing to find prognostic markers which are direct, easy-to-interpret, cost-effective and preferably noninvasive [2].

Oxygen has been long since known to play a critical role in the response of tumour to radiation and has been proven to be a prognostic factor clinically [3].Many of the methods used to determine the oxygen saturation of cancerous tumours include the use of invasive techniques such as probes and assays [4] In this study, we reported the use of $\mathrm{SpO} 2$ values from Pulse oximetry as a non-invasive prognostic factor in patients with 
locally advanced disease and as a predictive factor for response to radiation therapy.

\section{METHODOLOGY}

\subsection{Study Details}

It is a single-institution, prospective pilot study conducted between October -November 2019. For each patient, detailed history and clinical evaluation, along with necessary haematological and radiological investigations were obtained. After counselling patients regarding disease status and study, informed consent was taken. Inclusion criteria included patients above 18 years of age and ECOG (Eastern Cooperative Oncology Group) status of 0-2 with biopsy-proven locally advanced malignancy. Exclusion criteria included patients with metastatic disease, post-operative status, prior neoadjuvant chemotherapy, co-morbidities such as uncontrolled diabetes, hypertension, chronic obstructive pulmonary disease or cardiac dysfunction. Patients with spirometry FEV1/FEV ratio of less than $70 \%$ were excluded from the study. Only patients with good respiratory effort were included in the study. Due to the possibility of mechanical airway obstruction in locally advanced bulky head and neck cancers and the confounding bias of effects of smoking and clinical sequelae of pulmonary tuberculosis (such as emphysema, atelectasis), only patients who were clinically asymptomatic and with clear lungs on chest CT scan were included in this study. Patients who underwent adjuvant surgery or chemotherapy within 6 weeks of completing concurrent chemoradiation were excluded.

\subsection{Treatment Details and Study Endpoint}

All underwent asimulation CT scan of the respective area to be treated. The head and neck patients were immobilised with a thermoplastic mask and simulated from vertex to carina; the esophageal patients were simulated from mandible till third lumbar vertebra; the cervix uteri lesion patients were simulated from diaphragm to mid-thigh. All received intravenous iodinated contrast during the simulation.

The primary and the significant nodes were delineated as single GTV (Gross Tumor Volume) and considered as ' $\mathrm{V}_{\text {initial }}=$ Volume prior to treatment in cc'. The CTV (Clinical Target Volume) and PTV (Planning Target Volume) were delineated according to guidelines. Patients were planned either by 3DCRT, IMRT or VMAT according to the physician's discretion. All patients were planned for aradical intent dose of radiation. Each patient's plans were iterated for the optimum tumor coverage and avoidance of organs at risk according to guidelines. All patients were evaluated for the feasibility of concurrent chemotherapy.

On the day of initiation of radiation treatment, $\mathrm{SpO} 2$ was measured on the middle finger of the left hand and recorded. Subsequently, daily $\mathrm{SpO} 2$ was recorded, once a day, just prior to each radiation fraction through all days of treatment. Weekly blood haemoglobin values were also noted. Six weeks posttreatment, a CT scan with intravenous iodinated contrast was done to assess response to treatment. The residual disease was delineated (Gross primary and nodes) and recorded as ' $\mathrm{V}_{\text {post- }}$ treatment $=$ Volume post-treatment in cc'.

\subsection{Statistical Methods and Endpoints}

Tabulation was done and graphs were generated using Microsoft excel. The daily $\mathrm{SpO} 2$ values through out the treatment were tabulated and mean $\mathrm{SpO} 2$ for each patient was calculated. Weekly blood haemoglobin values were also tabulated and the mean haemoglobin value for each patient was calculated. Patients were categorized into two groups: those with $\mathrm{SpO} 2$ values equal to or more than $98 \%$ as 'better $\mathrm{SpO} 2$ group' and those with $\mathrm{SpO} 2$ values $97 \%$ and lower as 'poor $\mathrm{SpO} 2$ group'.

IBM -SPSS was used for analysis of the data. Student's ttest was applied to evaluate the difference in mean between the 'better' and 'poor' SpO2 groups. Spearman's rho analysis was employed to correlate the tumour volumes at baseline $\left(\mathrm{V}_{\text {initial }}\right)$ and response volumes $\left(\mathrm{V}_{\text {post-treatment }}\right)$ with the mean $\mathrm{SpO} 2$ and mean haemoglobin values. A ' $p$ ' value of $<0.05$ was considered significant.

\section{RESULTS}

A total of 10 patients were enrolled in this pilot study, which included 8 males and 2 females (Table 1). The mean age of this group was 56 years (range: 38-77 years). All had locally advanced disease (stage III and IV, non-metastatic) of which 6 had head and neck cancers, 2 had oesophageal tumours and 2 had cervical cancers. The head and neck patients received a total dose of $70 \mathrm{~Gy}$ in 35 fractions, 2 Gy per fraction, one fraction per day over 7 weeks, the oesophageal tumours received a total dose of 50.4 Gy in 28 fractions, 1.8 Gy per fraction, one fraction per day, over 6 weeks; cancer cervix uteri patients received 45 Gy in 25 fractions, 1.8 Gy per fraction, one fraction per day, over 5 weeks followed by Brachytherapy 7 Gy x 3 fractions. Out of 10 patients, eight received concurrent weekly CDDP chemotherapy; two head and neck patients did not receive any concurrent chemotherapy in view of renal co-morbidities. All patients completed the planned therapy without any treatment breaks.

None of the patients smoked during the study period. 6 out of 10 patients had aprevious history of smoking and 2 patients had sputum-negative, treated pulmonary tuberculosis with no lung sequelae. All patients had good respiratory effort throughout the treatment (Table 2).

Analysing all patients together (Table 3), for $n=10$ patients, the mean burden of tumour at baseline $\mathrm{V}_{\text {initial }}$ mean was $85.99 \mathrm{cc}$ [range: $20.2-242 \mathrm{cc}$ ]. Following radiation therapy, the ' $\mathrm{V}$ post' had reduced to a mean of $27.37 \mathrm{cc}$ [range: $0-92.2 \mathrm{cc}$ ]. Hence all patients responded to radiation and the mean reduction in tumor volume by $67.7 \%$ compared to baseline.

The patients were analysed further by grouping them into two categories. The mean SpO2 reading of each patient throughout the treatment period was tabulated and patients were categorised into poor $\mathrm{SpO} 2$ (less than 97\%) and better $\mathrm{SpO} 2$ (more than or equal to $98 \%$ ) groups. Student's t-test was employed to correlate the mean of the two groups to the reduction in disease (Table 4). It was found that patients with poor $\mathrm{SpO} 2$ had a mean residual disease of $77.1 \mathrm{cc}$ (standard deviation \pm 21.356 ) and patients with better $\mathrm{SpO} 2$ had lower mean residual disease of $14.938 \mathrm{cc}$ (standard deviation 
$\mathrm{A} \pm 11.5772$ )(see Graph 1). In simple words, patients with $<97 \mathrm{mmHg}$ SpO2 will have a larger residual disease at the end of treatment and hence respond poorly to radiation. Patients with mean $\mathrm{SpO} 2 \geq 98 \mathrm{mmHg}$ respond better to treatment and the tumour reduction/response is greater to radiation.(see Graph 2 and 3)

According to RECIST criteria 1.1, one patient [who belonged to the 'better $\mathrm{SpO} 2$ ' group] had complete response, i.e., no residual disease, the rest nine had a partial response (more than $30 \%$ reduction). None had progressive or stable disease.
Spearman's rho analysis showed a negative correlation between mean $\mathrm{SpO} 2$ and bulk of disease at presentation $(-0.675$, Table 5). This leads to the interpretation that patients with poorer mean $\mathrm{SpO} 2$ present with bulkier disease and patients with better $\mathrm{SpO} 2$ have lesser tumor burden at presentation (see Graph 4)

The mean haemoglobin of the patients through the treatment was $12.16 \mathrm{~g} / \mathrm{dl}$ [range: $11.2-14 \mathrm{~g} / \mathrm{dl}$ ]. There was no correlation between haemoglobin with either disease response or SpO2 levels (Table 6 and Graph 5).

Table 1. Patient characteristics and treatment details.

\begin{tabular}{|c|c|c|c|c|c|c|c|c|c|c|c|c|}
\hline $\begin{array}{c}\text { Patient } \\
\text { ID }\end{array}$ & Sub-site & Gender & Age & $\begin{array}{l}\text { Presenting } \\
\text { Symptom }\end{array}$ & $\begin{array}{c}\text { History } \\
\text { of } \\
\text { Smoking }\end{array}$ & Histology & $\begin{array}{l}\text { Stage of } \\
\text { Disease }\end{array}$ & $\begin{array}{l}\text { Radiation } \\
\text { Dose }\end{array}$ & $\begin{array}{c}\text { Concurrent } \\
\text { Chemotherapy }\end{array}$ & $\mathrm{V} 1(\mathrm{ccc})$ & $\mathrm{V} 2(\mathrm{cc})$ & $\begin{array}{l}\text { Mean } \\
\text { SpO2 }\end{array}$ \\
\hline 1 & Hypo pharynx & Male & 65 & $\begin{array}{c}\text { Pain on } \\
\text { swallowing } \\
\text { (odynophagia) }\end{array}$ & Yes & $\mathrm{sec}$ & T4aN1 & $* 70 / 35$ & No & 25.3 & 12.5 & 98.17 \\
\hline 2 & $\begin{array}{l}\text { Base of } \\
\text { Tongue }\end{array}$ & Male & 67 & $\begin{array}{c}\text { Pain on } \\
\text { swallowing } \\
\text { (odynophagia) }\end{array}$ & Yes & $\mathrm{scc}$ & $\mathrm{T} 4 \mathrm{aN} 2 \mathrm{~b}$ & $* 70 / 35$ & Yes & 62 & 14 & 98.36 \\
\hline 3 & Cervix uteri & Female & 57 & $\begin{array}{l}\text { Bleeding per } \\
\text { vaginum }\end{array}$ & No & $\mathrm{scc}$ & IIIB & $\begin{array}{c}{ }^{(} 50 / 25+ \\
\text { ISBT 7Gyx3\# }\end{array}$ & Yes & 209.5 & 92.2 & 97.36 \\
\hline 4 & Nasopharynx & Female & 38 & $\begin{array}{c}\text { Bleeding from } \\
\text { nostrils }\end{array}$ & No & undifferentiated & T3N2 & @ $50 / 25+24 / 12$ & Yes & 45.9 & 0 & 97.53 \\
\hline 5 & Hypopharynx & Male & 44 & $\begin{array}{c}\text { Pain on } \\
\text { swallowing }\end{array}$ & No & $\mathrm{scc}$ & $\mathrm{T} 4 \mathrm{aN} 2 \mathrm{~b}$ & $* 70 / 35$ & Yes & 23.7 & 5.03 & 98.73 \\
\hline 6 & Cervix uteri & Female & 39 & $\begin{array}{l}\text { Bleeding per } \\
\text { vaginum }\end{array}$ & No & $\mathrm{scc}$ & IIIB & $\begin{array}{c}50 / 25+ \\
\text { ISBT:7Gyx3\# }\end{array}$ & Yes & 242 & 62 & 97.2 \\
\hline 7 & Esophagus & Male & 56 & $\begin{array}{l}\text { Difficulty in } \\
\text { swallowing } \\
\text { (Dysphagia) }\end{array}$ & Yes & $\mathrm{scc}$ & T4N0 & ${ }^{\#} 50.4 / 28$ & Yes & 125.5 & 33.01 & 99.08 \\
\hline 8 & Supraglottis & Male & 77 & $\begin{array}{c}\text { Hoarsnes of } \\
\text { voice }\end{array}$ & Yes & $\mathrm{scc}$ & $\mathrm{T} 3 \mathrm{~N} 2 \mathrm{c}$ & $* 70 / 35$ & No & 72 & 31 & 97.88 \\
\hline 9 & Esophagus & Male & 53 & $\begin{array}{l}\text { Difficulty in } \\
\text { swallowing } \\
\text { (Dysphagia) }\end{array}$ & Yes & $\mathrm{scc}$ & T4N0 & ${ }^{\#} 50.4 / 28$ & Yes & 33.8 & 14 & 98.68 \\
\hline 10 & Vallecula & Male & 65 & $\begin{array}{c}\text { Pain while } \\
\text { swallowing } \\
\text { (odynophagia) }\end{array}$ & Yes & $\mathrm{scc}$ & T3N0 & $* 70 / 35$ & Yes & 20.2 & 10 & 98.58 \\
\hline
\end{tabular}

abbreviation: scc=squamous cell carcinoma;; V1=volume of disease prior to treatment; $\mathrm{V} 2=$ volume of residual disease post-treatment; $* 2 \mathrm{~Gy}$ per fraction, one fraction per day, over 7 weeks; \# 1,8 Gy per fraction, one fraction per day, over 6 weeks; @ 2 Gy per fraction, one fraction per day, over 5 weeks followed by ISBT(Interstitial Brachytherapy) 7 Gy in 3 fractions over 2 weeks; cDDP $40 \mathrm{mg} / \mathrm{m}^{2}$ weekly; patients 3 and 5 had past pulmonary tuberculosis, treated and tested sputum-negative before initiation of treatment.

Table 2. Patient characteristics and treatment details.

\begin{tabular}{|c|c|c|}
\hline- & SpO2 $<\mathbf{9 7} \mathbf{m m H g}$ & SpO2 \% 98 \\
\hline Number of patients & 2 & 8 \\
\hline Subsite & Cervix uteri=2 & Nasopharynx $=1$ \\
& & Base of Tongue 1 \\
Vallecula $=1$ & Hypopharynx $=2$ \\
& \\
& & Supraglottis $=1$ \\
Esophagus $=1$ \\
\hline Histology & & 7 \\
Squamous cell carcinoma & & 1 \\
\hline
\end{tabular}


(Table $\square$ \) contd.....

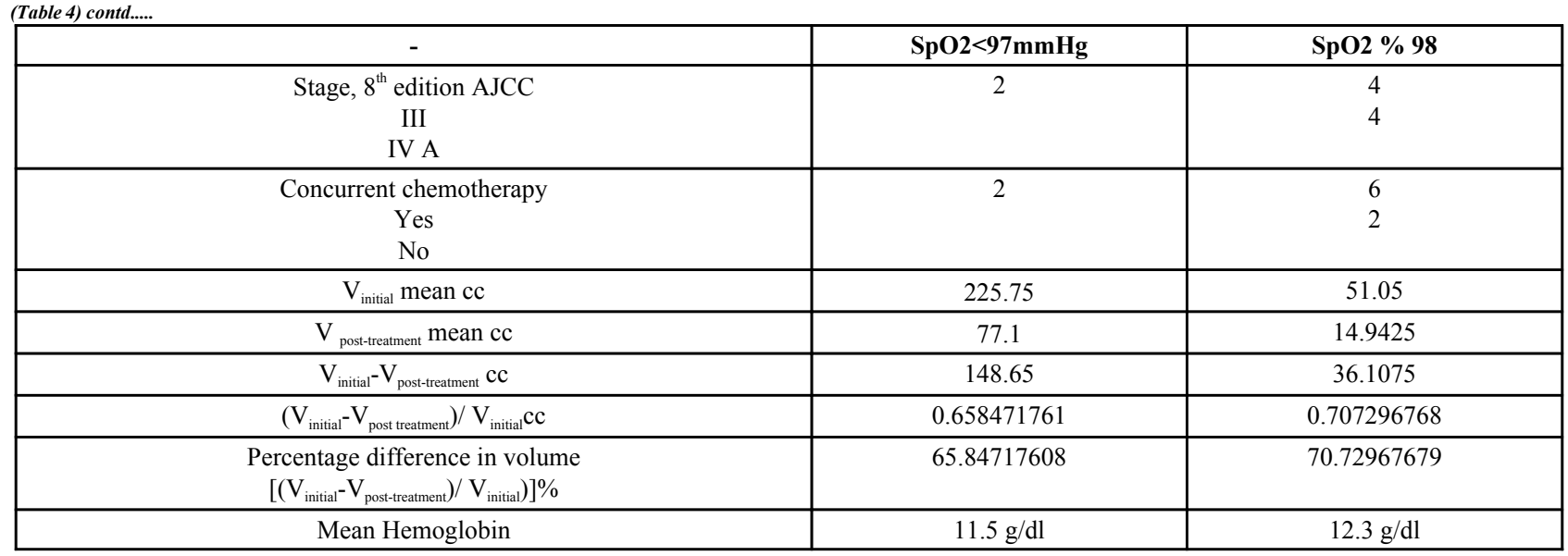

Table 3. Analyses of all patients, $n=10$.

\begin{tabular}{|c|c|c|}
\hline Parameter & Mean & Range \\
\hline V initial & $85.99 \mathrm{cc}$ & $20.2-242 \mathrm{cc}$ \\
\hline V post-treatment & $27.37 \mathrm{cc}$ & $0-92.2 \mathrm{cc}$ \\
\hline $\begin{array}{c}\text { Percentage reduction in volume } \\
{[(\mathrm{V} 1-\mathrm{V} 2) \mathrm{A} \text { V1] } \%}\end{array}$ & $67.7 \%$ & $50.7-100 \%$ \\
\hline SpO2 readings & $98.16 \%$ & $95-100 \%$ \\
\hline Haemoglobin & $12.16 \mathrm{~g} / \mathrm{dl}$ & $11.2-14 \mathrm{~g} / \mathrm{dl}$ \\
\hline
\end{tabular}

Table 4. Student's t-test analysis between $\mathrm{V}_{\text {post-treatment }}$ and mean of SpO2 of the two groups.

\begin{tabular}{|c|c|c|c|c|c|c|}
\hline t-Test & SpO2 group & $\mathbf{N}$ & Mean & Standard deviation & Standard Error Mean & p value \\
\hline \multirow[t]{2}{*}{$\mathrm{V}_{\text {post treatment }}$} & $<97 \mathrm{mmHg}$ & 2 & 77.100 & 21.3546 & 15.1000 & $<0.001$ \\
\hline & (poor $\mathrm{SpO} 2$ ) \% 98mmHg (better $\mathrm{SpO} 2$ ) & 8 & 14.938 & 11.5772 & 4.0932 & significant \\
\hline
\end{tabular}

\section{mean of post- \\ treatment \\ volume(cc)}

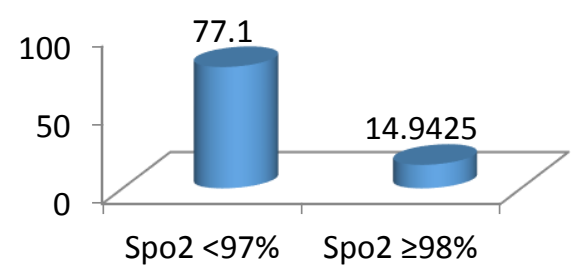

Graph (1). Patients with poor $\mathrm{SpO} 2$ values have more residual disease at the end of therapy compared to patients with better $\mathrm{SpO} 2$ values (mean 77.1 cc vs $14.94 \mathrm{cc})$. 


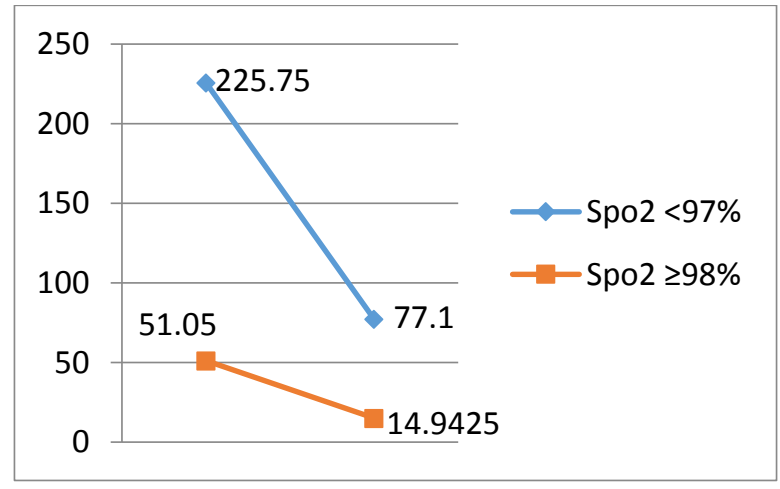

Graph (2). Line graph illustrating the pattern of reduction of tumor between the two groups.

Table 5. Spearman's rho analysis.

\begin{tabular}{|c|c|c|}
\hline $\mathbf{V}_{\text {initial }}$ with SpO2 & correlation coefficient & sig.(2 tailed) \\
\hline & -0.675 & 0.032 \\
\hline
\end{tabular}

\section{$\%$ Reduction of}

\section{tumor}

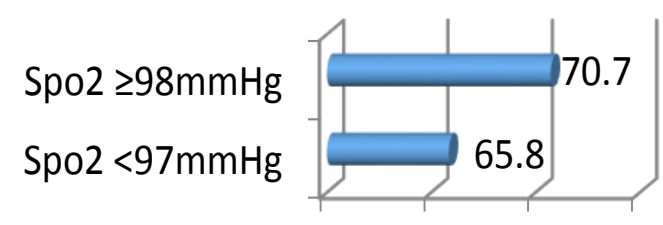

$\begin{array}{llll}60 & 65 & 70 & 75\end{array}$

Graph (3). Percentage reduction of disease between the two $\mathrm{SpO} 2$ groups. The reduction is more in patients with $\mathrm{SpO} 2 \%$ $98 \mathrm{mmHg} .(70.72 \%$ vs $65.84 \%)$.

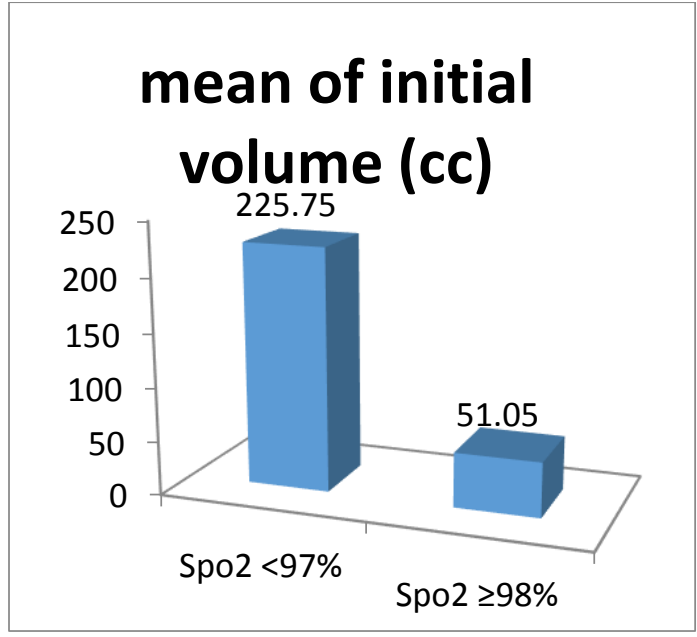

Graph (4). Patients with poor $\mathrm{SpO} 2$ present with bulkier disease compared to patients with better $\mathrm{SpO} 2$ who have a lesser burden of disease at presentation (mean: $225.75 \mathrm{cc}$ vs $51.05 \mathrm{cc}$ ).

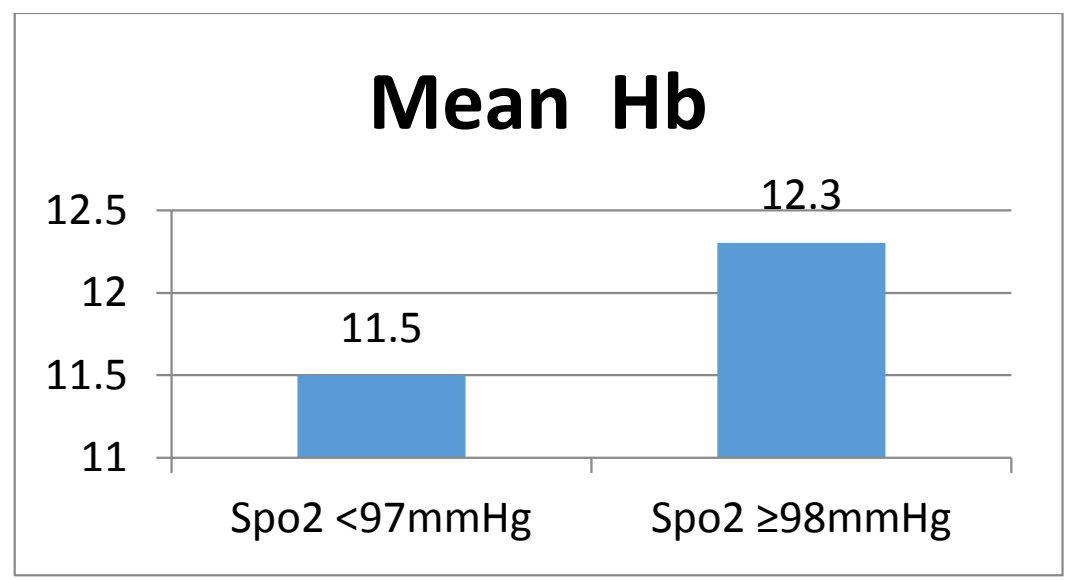

Graph (5). Mean haemoglobin between the two groups. 
Table 6. Student's t-test analysis between mean hemoglobin and mean of $\mathrm{SpO} 2$ of the two groups.

\begin{tabular}{|c|c|c|c|c|c|c|}
\hline t-test & SpO2 group & $\mathbf{N}$ & Mean & Standard deviation & Standard Error Mean & p value \\
\hline- & $\begin{array}{c}<97 \mathrm{mmHg} \\
\text { (poor SpO2) }\end{array}$ & 2 & 11.5 & 2.12 & 1.5 & Not significant \\
\hline- & $\begin{array}{c}\% 98 \mathrm{mmHg} \\
\text { (better SpO2 }\end{array}$ & 8 & 12.38 & 1.061 & 0.375 & Not significant \\
\hline
\end{tabular}

\section{DISCSSION}

Many prognostic and predictive factors are available clinically to aid in the treatment, management and counselling of oncology patients. Amongst the 6 'R's of radiobiology, reoxygenation has been explored extensively, both theoretically and clinically. Since theearly 90 s, studies on tumour tissue of various sites such as Head and neck and cervical cancers have demonstrated prognostic significance of intra-tumoral oxygenation and $\mathrm{pH}$. This applied knowledge has led to the emergence of strategies such as theuse of vasoactive agents, hyperbaric oxygen, hyperthermia, radiosensitizers and hypoxic cell modifiers [5]. The use of altered fraction regimens of hyperfractionation to increase functional oxygenation has been tried [6]. Non-invasive imaging techniques such as PET scans $-{ }^{18} \mathrm{~F}$ FMISO, ${ }^{18} \mathrm{~F}$ FAZA- based on the principles of hypoxia are on the rise [7].There is ongoing research to combine targeting hypoxia and immune check-points to augment immunological response of the host [8].

In this study, the patients' daily $\mathrm{SpO} 2$ measurements during treatment were studied and correlated with disease response. The aim was to find out if $\mathrm{SpO} 2$ values of the patient can be used as a surrogate for the oxygenated status of the oncology patients and be used clinically as prognostic and predictive markers.

The functioning of pulse oximetry is based on the principle of spectrophotometry, where the absorption of light is measured using two wavelengths: $660 \mathrm{~nm}$ (red) for oxygenated and $940 \mathrm{~nm}$ (infrared) for deoxygenated blood. The ratio of absorbance at these wavelengths is calibrated against direct measurements of arterial oxygen saturation $(\mathrm{SaO} 2)$ to establish the pulse oximeter's measure of arterial saturation (SpO2).It is easy to use, cost-effective, non-invasive and reproducible as well as portable [9]. It has its own limitations, such as inability to detect accurate saturation in conditions such as dyshemoglobinemias (carboxyhemoglobinemia and methemoglobinemia), high arterial oxygen tensions and low perfusion states (low cardiac output, vasoconstriction, and hypothermia) [10].

In this study, patients with locally advanced lesions were treated with chemoradiation. The category of patients with poor $\mathrm{SpO} 2$ levels $(<97 \mathrm{mmHg})$ had more residual disease at the end of treatment and hence poorer response to treatment. The patients with better $\mathrm{SpO} 2$ levels $(\geq 98 \mathrm{mmHg}$ ) had lesser residual disease at the end of treatment comparatively, so probably these tumors were better oxygenated. Radiation causes tissue damage through the formation of free radicals [7].The free radicals react rapidly with oxygen to 'fix the damage'. Conversely, under hypoxic conditions, this pattern of damage is reduced, thus resulting in radiation resistance and local recurrence of the tumor [11].In addition, hypoxia may indirectly promote radioresistance through gene modification, decrease apoptotic potential, thereby reducing theradiosensitivity of the tumor. The transcriptional regulators of hypoxia, namely HIF-1 and HIF-2 and target genes such as carbonic an hydrase 9 and glucose transporter-1, are reported to have prognostic significance in numerous tumor types [12, 13].

Hypo-oxygenated status has been shown to harbour more aggressive patterns of disease. These tumors present with higher stages at diagnosis, with an increased propensity for metastasis, resistance to therapy and poor survival [11]. In our study, it was observed that patients with poor $\mathrm{SpO} 2$ levels had bulkier disease at diagnosis than patients with better $\mathrm{SpO} 2$.

In a study by Martins et al., pulse oximetry was found to be a prognostic marker in lung cancer patients [14]. A survival model was developed in these locally advanced lung cancer patients, which included age, performance status, stage and histology. It was found that $\mathrm{SpO} 2>95 \%$ was a prognostic marker and an independent predictor of survival.

Anemia is one of the clinically proven prognostic factors. Studies performed on carcinoma cervix have shown that patients with haemoglobin levels less than $10-13 \mathrm{~g} / \mathrm{dl}$ have poorer 5 -yr survival $[3,15,16]$. Similarly, in head and neck cancer patients, low haemoglobin levels $(<13 \mathrm{~g} / \mathrm{dl}$ for males, $<11.5 \mathrm{~g} / \mathrm{dl}$ for females) predicted poorer loco-regional control and overall survival [17]. However, in our study, there was no significant correlation between mean haemoglobin values with areduction in the tumor. Since this is a pilot study, more patients need to be recruited and analysed for the same.

\section{LIMITATION OF THE STUDY}

This pilot study was performedon a small sample size of 10 patients in a heterogeneous group. Our next endeavour is to include more patients and to categorise them according to site, subsite, histology, tumour markers and correlate $\mathrm{SpO} 2$ measurements with the in-vitro assessment of tumour $\mathrm{pH}[5$, 18 ] and oxygen probes along with studies on gene signatures [12].

\section{CONCLUSION}

Patients with lower $\mathrm{SpO} 2$ tend to present with bulkier disease at diagnosis and also respond poorly to concurrent chemotherapy. $\mathrm{SpO} 2$ readings can be potentially used as a surrogate for tumor oxygenation status in oncology patients. Since it is widely available, easy-to-interpret and non-invasive, it is prudent to further explore its role as a prognostic and predictive indicator in oncology. This pilot study should be done on a larger heterogeneous study population in conjunction with tumor-in-vitro studies and gene-signatures. 


\section{ETHICS APPROVAL AND CONSENT TO PARTI- CIPATE}

The author confirms that since the estimation of $\mathrm{SpO} 2$ measurements is a part of routine OPD procedure, it is a noninvasive, 'low-risk' project and does not raise significant ethical issues, only supervisor's (i.e., co-author in this project) approval has been sought.

\section{HUMAN AND ANIMAL RIGHTS}

Not Applicable.

\section{CONSENT FOR PUBLICATION}

Written informed consent was obtained from all participants.

\section{AVAILABILITY OF DATA AND MATERIALS}

The authors confirm that the data supporting the findings of this study are available within the article.

\section{FUNDING}

None.

\section{CONFLICT OF INTEREST}

The authors declare no conflicts of interest, financial or otherwise.

\section{ACKNOWLEDGEMENTS}

Declared none.

\section{REFERENCES}

[1] Paesmans M. Prognostic and Predictive factors for lung cancer. Breathe (Sheff) 2012; 9(2)

[http://dx.doi.org/10.1183/20734735.006911]

[2] Einoch Amor R, Nakhleh MK, Barash O, Haick H. Breath analysis of cancer in the present and the future. Eur Respir Rev 2019; 28(152) 190002

[http://dx.doi.org/10.1183/16000617.0002-2019] [PMID: 31243094]

[3] Bush RS. Anemia in radiation therapy, IJROBP,November 1986; 12(1)

[4] Anderson et al. Probe for the measurement of cell surface $\mathrm{pH}$ in vivo and ex vivo, PNAS 2016; 113(29): 8177-81.
[5] Horsman MR, Overgaard J. Hypoxia and radiotherapy. J Radiat Res (Tokyo) 2016; 57(S1): i90-8.

[http://dx.doi.org/10.1093/jrr/rrw007] [PMID: 26983987]

[6] Thames HD, et al. AcceleratedFractionatoin vs Hyperfractionation : Rationales for several treatments per day, IJROBP , February 1983; 9(2)

[7] Daimiel I. Insights into hypoxia: non-invasive assessment through imaging modalities and its application in breast cancer. J Breast Cancer 2019; 22(2): 155-71.

[http://dx.doi.org/10.4048/jbc.2019.22.e26] [PMID: 31281720]

[8] Walker PR. Let there be oxygen and T cells. J Clin Invest 2018; 128(11): 4761-3.

[http://dx.doi.org/10.1172/JCI124305] [PMID: 30320602]

[9] Jubran A. Pulse oximetry. Crit Care 2015; 19: 272. [http://dx.doi.org/10.1186/s13054-015-0984-8] [PMID: 26179876]

[10] Blaisdell CJ, Goodman S, Clark K, Casella JF, Loughlin GM. Pulse oximetry is a poor predictor of hypoxemia in stable children with sickle cell disease. Arch Pediatr Adolesc Med 2000; 154(9): 900-3. [http://dx.doi.org/10.1001/archpedi.154.9.900] [PMID: 10980793]

[11] Al Tameemi W, Dale TP, Al-Jumaily RMK, Forsyth NR. Hypoxiamodified cancer cell metabolism. Front Cell Dev Biol 2019; 7: 4 . [http://dx.doi.org/10.3389/fcell.2019.00004] [PMID: 30761299]

[12] Jubb AM, Buffa FM, Harris AL. Assessment of tumour hypoxia for prediction of response to therapy and cancer prognosis. J Cell Mol Med 2010; 14(1-2): 18-29.

[http://dx.doi.org/10.1111/j.1582-4934.2009.00944.x] [PMID: 19840191]

[13] Yang L, West CML. Hypoxia gene expression signatures as predictive biomarkers for personalising radiotherapy. Br J Radiol 2019; 92(1093)20180036 [PMID: 29513038]

[14] Martins SJ, Ho N, Cavamura SO, Harada CM, Yamamoto CA, Takagaki TY. Lung cancer symptoms and pulse oximetry in the prognostic assessment of patients with lung cancer. BMC Cancer 2005; 5: 72.

[http://dx.doi.org/10.1186/1471-2407-5-72] [PMID: 16000170]

[15] Harrison LB, Chadha M, Hill RJ, Hu K, Shasha D. Impact of tumor hypoxia and anemia on radiation therapy outcomes. Oncologist 2002; 7(6): 492-508.

[http://dx.doi.org/10.1634/theoncologist.7-6-492] [PMID: 12490737]

[16] Mundt AJ, Connell PP, Campbell T, Hwang JH, Rotmensch J, Waggoner S. Race and clinical outcome in patients with carcinoma of the uterine cervix treated with radiation therapy. Gynecol Oncol 1998; 71(2): 151-8

[http://dx.doi.org/10.1006/gyno.1998.5203] [PMID: 9826453]

[17] Grant DG, Hussain A, Hurman D. Pre-treatment anaemia alters outcome in early squamous cell carcinoma of the larynx treated by radical radiotherapy. J Laryngol Otol 1999; 113(9): 829-33.

[http://dx.doi.org/10.1017/S0022215100145323] [PMID: 10664687]

[18] Boedtkjer, et al. The acidic tumor microenvironment as a driver of cancer, annual review of physiology, annu. Rev Physiol 2020; 82: 21.1-21.24.

This is an open access article distributed under the terms of the Creative Commons Attribution 4.0 International Public License (CC-BY 4.0), a copy of which is available at: https://creativecommons.org/licenses/by/4.0/legalcode. This license permits unrestricted use, distribution, and reproduction in any medium, provided the original author and source are credited. 